\title{
A Review on Natural Ventilation-Enabling Façade Noise Control Devices for Congested High-Rise Cities
}

\author{
Shiu-Keung Tang \\ Department of Building Services Engineering, The Hong Kong Polytechnic University, Hong Kong, China; \\ shiu-keung.tang@polyu.edu.hk \\ Academic Editor: Tribikram Kundu \\ Received: 14 December 2016; Accepted: 6 February 2017; Published: 13 February 2017
}

\begin{abstract}
This review summarizes the current status of the research and development of natural ventilation-enabling noise control devices for use on the façades of high-rise residential buildings in congested cities. These devices are important for a sustainable urbanized city, as they are supposed to offer good acoustical protection to citizens, allowing for an acceptable level of natural ventilation inside residential units; energy for mechanical ventilation can then be saved. From the information presented in the existing literature, it is concluded that protrusive devices, such as lintels and balconies, are not effective noise screening devices, even if they are installed with sound absorbers and/or reflectors, under the effect of city reverberation. On the contrary, plenum windows and similar structures, which are plenum structures with a staggered air inlet and outlet, are interesting alternatives that are worth rigorous considerations.
\end{abstract}

Keywords: noise reduction; traffic noise; natural ventilation; building façade

\section{Introduction}

Excessive exposure to noise is hazardous to human health. Kang et al. [1] stated that, "prolonged exposure to noise, even at a level lower than statutory limits, can cause serious physiological and psychological symptoms". A recent report of the World Health Organization illustrates that noise has become the second most important environmental cause of death and disability in Western Europe [2]. Although no similar survey has been conducted outside of Europe, to the knowledge of the author, it is believed that noise pollution has become a worldwide problem.

The major source of noise pollution in a densely populated high-rise city, is ground traffic. However, controlling traffic noise exposure in such a city is never an easy task. It cannot be solved by simply migrating citizens, so that they live in sub-urban or even relatively rural areas, as the transportation network necessary for this migration will significantly disturb the originally quiet environment. Noise attenuation devices which are stronger than those used in the urban areas, may be required to reduce the annoying effect of the intrusive noises emitted by the relatively intermittent vehicles, in a low background noise environment [3]. Greenery views and sea views are able to moderate human noise annoyance responses [4-6]. It has also been found that the visibility of noise sources can affect human noise annoyance (for instance, Zhang et al. [7] and Aletta et al. [8]). However, such views cannot help when the traffic noise levels that have to be dealt with, can easily exceed $80 \mathrm{dBA}$.

Urban re-development, with the aim of creating residential spaces, is essential for a densely populated city with limited land that is suitable for residential purposes. However, such development is also making the, already very challenging noise control, even more challenging. This is because the targeted areas were not categorized for residential land use in the past and are mostly uninhabited, because of unacceptable noise levels. Since more and more people will be living in cities in the 
future [9], urban noise mitigation has become increasingly important in town planning. Effective noise mitigation measures urgently need to be developed.

Roadside noise barriers and enclosures are very common, as well as traditional noise mitigation measures [10]. They reduce the citizens' exposure to traffic noise by obstructing the direct-line-of-sight between the traffic and the residential units in their shadow zones. There have been extensive studies on their applications and performances (for instance [11,12]). However, these massive structures occupy relatively large pieces of land, in order to accommodate their foundations. Also, it is undesirable to build residential units close to a barrier because of the risk of an adverse standing acoustic wave setup [13], and air movement restrictions. A noise enclosure tends to trap noise energy, and thus, the areas in the proximity of its exits/entrances are not suitable for residential purposes, due to the strong noise radiation which is emitted from the enclosure [14]. Furthermore, the high construction and land costs make them very cost ineffective for attenuating noise. Besides, the barriers and enclosures may have adverse visual impacts, so they are not always welcomed by the citizens. Moreover, they cannot be adopted in urban re-development projects, due to the lack of space in these very congested areas.

Setbacks and extended podia [15] can help reduce noise exposure, but again, these measures tend to sacrifice buildable land areas and spaces, reducing the number of residential units that can theoretically be created. In a congested city, noise barriers, enclosures, setbacks, and extended podia, are therefore not desirable noise pollution solutions. The use of noise insensitive buildings as noise barriers, and a more careful street canyon design, have been proposed [15-17], but these approaches are also not easy to implement in a densely built environment, again due to the shortage of land.

Closing the windows of a residential unit is perhaps the most straight-forward way to prevent noise intrusion. However, this is achieved at the expense of natural ventilation, and therefore, fixed windows are not realistic options in modern practice, even when air conditioning/mechanical ventilation is provided. Double and triple glazed windows [18], and those equipped with mechanical ventilators [19], are very effective façade devices for noise reduction. However, these devices either do not allow for natural ventilation, or they have to consume energy to provide the necessary ventilation. When considering the concept of sustainability, they can not be the preferred noise mitigation measures. The development of a device/measure which can satisfactorily attenuate noise and, at the same time, allow for a reasonable level of natural ventilation, has become the focus in recent years. Noise attenuation and natural ventilation provision are, however, in conflict. Without an acceptable strategy, the number of new residential units that can be created during urbanization or urban re-development, will be largely limited.

De Salis et al. [20] presented a review on the noise control strategies for naturally ventilated buildings in 2002, and there have been many updates on this topic since its publication. The present review summarizes the continuous effort made in recent years by the research community, to develop natural ventilation-enabling noise control devices that can be installed at, or near to, openings on the façade of a high-rise building. For the sake of completeness, relevant devices reviewed by De Salis et al. [20] are also included and updated. Section 2 discusses the acoustical performance of these devices. It is followed by a discussion on their limitations and future challenges, in Section 3. Section 4 concludes this review.

\section{Natural Ventilation-Enabling Façade Noise Control Devices}

The traffic noise reduction performance of the devices is the main concern of this review. Figure 1 shows the shapes of two commonly adopted traffic noise spectra [21,22], and some examples of those measured in-situ at building façades located between $10 \mathrm{~m}$ to $20 \mathrm{~m}$ above busy trunk roads, recorded by the author during busy traffic hours. Although the traffic noise spectral content varies between studies, it is believed that the shapes of these spectra within the most important frequency bands are somewhat similar. Normalized traffic noise spectra are presented here, as they are recommended 
by the international standard for quantifying the noise reduction property of a frequency-sensitive device [21].

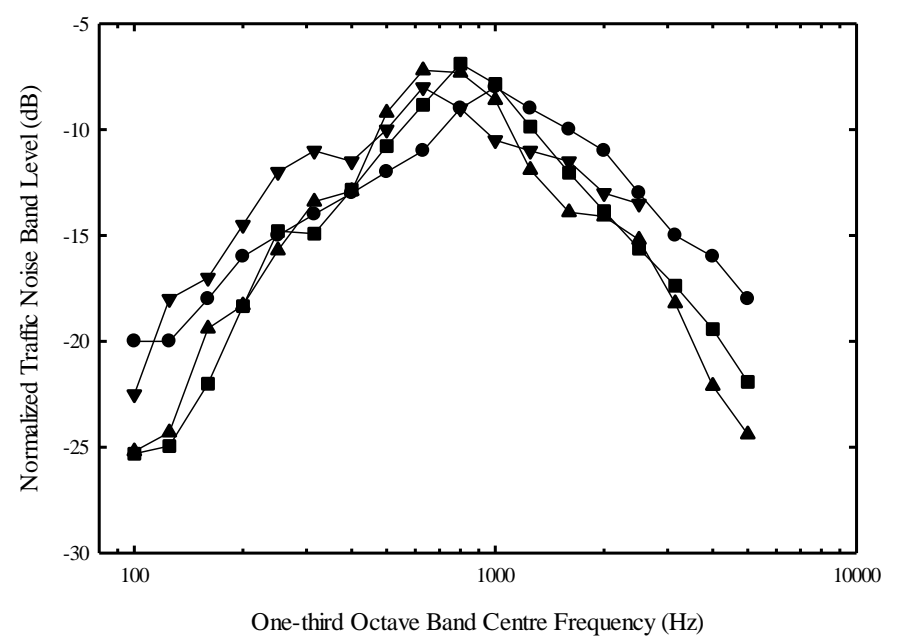

Figure 1. Examples of normalized traffic noise spectra. ๑: EN1793-3 [21]; $\mathbf{\nabla}$ : Delany et al. [22]; $\mathbf{\square}$ : in-situ measurement $1 ; \mathbf{\Delta}$ : in-situ measurement 2.

\subsection{Fins, Lintels, Screens, and Similar Protrusions}

The protrusions on the façade of a building next to a noisy road act as sound barriers and protect the windows behind them. Figure 2 illustrates the various forms of these devices which have previously been proposed by a number of researchers. As it is possible to open the windows, natural ventilation can be achieved. For a single apparatus of protrusion, the acoustical insulation may be calculated using the reduction in the view angle of the road seen by the receiver (windows/openings), as suggested in CRTN [23]. However, for a vertical fin, the protection will be largely limited because of the reflection by this fin, unless appropriate sound absorption is installed. When a window is located between two vertical fins, this situation is even worse, because of the multiple reflections between the fins. Janczu et al. [24] numerically illustrated the noise distribution within a vertical re-entrant region of a high-rise building facing a parallel road. The channel-like dual-fin structure resembles a re-entrant region, which tends to direct the noise energy to the upper floors. The maximum traffic noise protection which can be offered by a vertical fin, even with sound absorption, is believed to be less than $3 \mathrm{~dB}$.

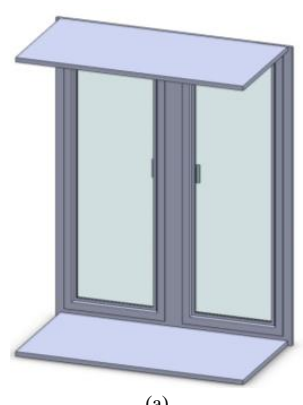

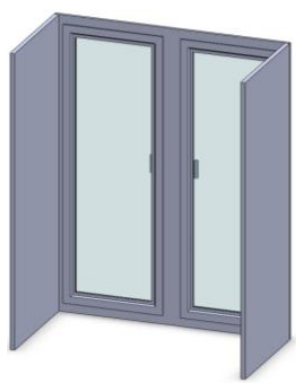

(b)

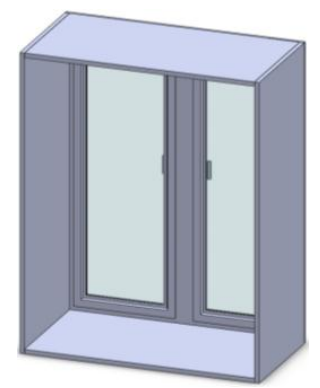

(c)

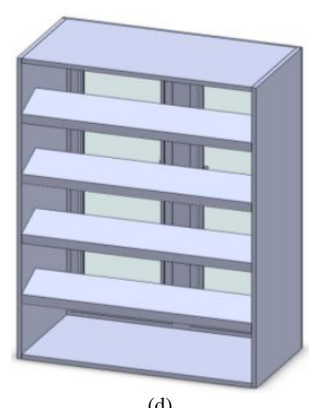

(d)

Figure 2. Examples of protrusive devices (excluding balconies). (a) Lintels; (b) vertical fins; (c) eaves; (d) eaves with louvers.

Lintels installed on building façades are horizontal canopies, as well as sound barriers when noise sources are located below them. Thus, they can theoretically help screen traffic noise. Tadeu et al. [25] numerically studied the sound attenuation achieved by the installation of thin rigid horizontal screens 
on building façades. The effect of the shapes of these screens on the acoustical protection was also examined. It was found that a circumference-arc-shaped screen performed better than a straight inclined screen, in terms of the acoustical protection, provided that the locations of the edges were unchanged. However, the screens were not found to be useful at the lower floors of a high-rise building, where the reflection from the screen of the immediate upper floor was significant enough to erase the sound barrier effect of the lower screen. Therefore, sound absorption needs to be installed on the reflecting surfaces of the screens [26]. However, these screens are not effective noise control devices when compared to balconies [27] (discussed later).

Eaves and louvers on the façade of a building can help reduce solar heat gain by providing shade. Sakamoto et al. [28] investigated the acoustical protection of different types of eaves and louvers, using scale model experiments. Similar to the results of the screens discussed above, the horizontal eaves/louvers did not provide meaningful acoustical protection, unless the sound incidence angle was large. Vertical louvers behaved in a similar way to vertical fins, and were less effective than the horizontal ones. Sound absorption was required in order to improve the overall acoustical performance (corresponding sound absorption coefficients were not provided). Sakamoto et al. [28] showed that the insertion losses of eaves, louvers, and their combinations, ranged from 1 to $10 \mathrm{~dB}$. However, the sound incidence angle has to be as large as $80^{\circ}$ for the insertion loss to be higher than $4 \mathrm{~dB}$. Martello et al. [29] showed that the installation of sound absorption $(7 \mathrm{~mm}$ thick polyurethane conglomerate of density $70 \mathrm{~kg} / \mathrm{m}^{3}$ ) onto the solar shading louvers, could help reduce the noise level by $\sim 5$ to $6 \mathrm{~dB}$ in the high frequency range $(1.6 \mathrm{kHz}$ to $5 \mathrm{kHz})$, when compared to those without absorption, for the case of a commercial building.

It should be noted that the above studies were completed without considering the reflections from neighbourhood buildings. In a congested city, the street canyon effect results in considerable city reverberation [30]. The acoustical protection of the abovementioned protrusions will be much reduced in the presence of random incident noises. However, recent research results show that external shading devices, like louvers, can help manipulate the various psycho-acoustical parameters [31]. This has a potential implication for future nuisance reduction strategies. Further research into this issue would be meaningful.

\subsection{Resonant Devices}

The use of resonators and similar devices, in conjunction with louvers and wall openings, has been proposed for attenuating external noise intrusion into indoor living environments. However, research in this direction has not been popular, mainly because of the limitations of these devices.

One example of these resonant devices is the tube array ventilator proposed by Field [32]. These tubes act as quarter wavelength resonators, which are able to stop the sound transmission by concerted resonance [33]. In his experiment, Field found that the weighted sound reduction index of his proposed device was around $22 \mathrm{~dB}$. However, the proposed ventilator occupied a large area of the opening and was quite bulky, for improved broadband performance. Also, the ventilator opening size was small, and thus, the air speed inside the ventilator air passage will only be high enough to generate aerodynamic noise if a sufficient ventilation rate is achieved. Besides, the ventilator was oblique to light, so additional window glazing needs to be installed for daylight utilization.

Asakura et al. [34] investigated the use of a long duct-like ventilation shaft on the top of a fixed window glazing for sound attenuation. Resonators and coupled cavities (created by parallel fins) were installed inside the ventilation shaft, in order to improve its broadband sound attenuation performance. The difference between the noise levels across the corresponding fixed window was about $20 \mathrm{~dB}$, which was just a few decibels above that of a closed window. Although the noise reduction was high, the small shaft openings, and the very long and narrow shaft design, results in unsatisfactory natural ventilation.

Nguyen et al. [35] studied the improvement of sound transmission loss across louvers/ventilation grilles, by installing cavity resonators inside the air passages within the louvers/grilles. These cavities 
had two openings for air penetration. The effects of their relative orientations on the sound attenuation were examined. These authors also predicted the corresponding sound transmission losses, by solving the wave equation. The sound attenuation of their prototypes varied between 2 and $9 \mathrm{~dB}$, from the $500 \mathrm{~Hz}$ to the $8 \mathrm{kHz}$ one-third octave bands. The performances of these devices at lower frequencies were not presented.

\subsection{Balconies}

A balcony on the façade of a building can provide an extended outdoor area with functionality, which cannot be achieved by indoor living spaces [36], and is very often welcomed by the residents. A balcony blocks the direct line-of-sight of a ground noise source from the receiver, while natural ventilation is possible. It has therefore attracted the attention of many researchers in the past few decades. A description of the various common balcony forms can be found in Tang [27]. These balcony forms are shown in Figure 3, for easy reference. The balcony was once regarded as a green design in terms of noise protection, but it is now understood that its acoustical protection is not obvious.

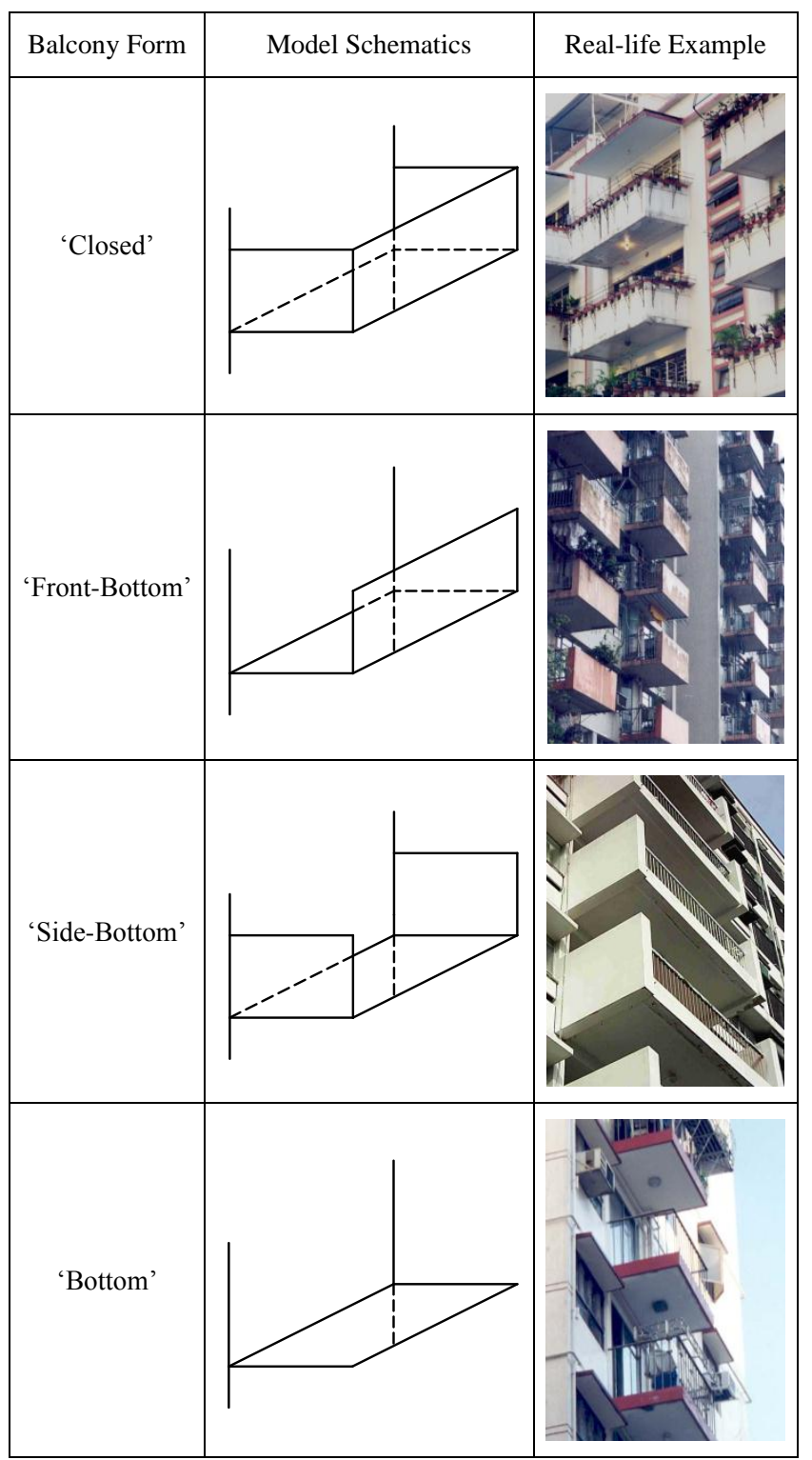

Figure 3. Common forms of high-rise building balconies (extracted from Tang [27]). Copyright Acoustical Society of America, 2005. 
In an open space with a noise source on the ground, a standalone balcony on a building façade provides significant acoustical protection to the areas beyond it. Mohsen and Oldham [37] carried out a detailed experimental investigation, using a 1:10 scale model, to study the effects of source orientation, balcony form (in terms of depth and with and without parapet), window opening size, and locations, on the acoustical protection. On average, a $\sim 5 \mathrm{~dB}$ insertion loss was recorded for a closed form balcony. Oldham and Mohsen [38] have also completed a theoretical analysis on the acoustical protection of a standalone balcony on a building façade.

Additionally, Oldham and Mohsen [39] suggested the use of a recessed building form for acoustical protection. The proposed recessed building form consisted of balconies arranged in the form of a terrace, reducing the jeopardizing reflection from the balcony ceiling, onto the windows or openings behind the balcony. The measured traffic noise reduction increased from $\sim 5 \mathrm{~dB}$ at a very small effective path difference, to $\sim 14 \mathrm{~dB}$ at an effective path difference of $1 \mathrm{~m}$ [39]. However, a recessed building form is not practical for a congested city, as it will largely reduce the number of residential units that can theoretically be built.

May [40] has performed a field measurement within the balconies of a high-rise building located next to a highway. Although a direct measurement of the balcony insertion loss could not be taken, his results show that the reflection from the balcony ceiling, as well as the multiple reflections within the balcony, can largely offset the noise screening effect of the balcony. Sound absorption is thus needed before a balcony on a high-rise building façade can be used as a noise screening device.

Conventional courtyards have high solid walls without ceilings, and thus, can offer high acoustical protection. Hammad and Gibbs [41,42] investigated the resultant acoustical protection when thnadners and splitters were applied to the courtyard wall, and the balcony front parapet facing the road traffic. A thnadner is a kind of shaped noise barrier [43]. For the courtyard cases, the use of a thnadner and splitter was shown to not significantly affect the acoustical protection, when compared to a solid wall, except at floor levels close to the ground/source. Hammad and Gibbs [41] showed that the protection of a courtyard with a thnadner ranged from 8 to $26 \mathrm{~dB}$, depending on the depth of the courtyard and the height of the courtyard above the ground. The corresponding protection for the splitter cases, varied between $10 \mathrm{~dB}$ and $27 \mathrm{~dB}$. Although the protection appears quite high, these devices have adverse effects on the natural ventilation. The multiple reflections inside a balcony with a ceiling tended to reduce the protection by $\sim 3 \mathrm{~dB}$, as shown by Hammad and Gibbs [42].

Recently, Tang [27,44] used a 3-storey scale model to study the effects of common high-rise building balcony forms on the acoustical insertion losses. The width-to-depth ratios of the adopted balconies were all 2:1. The source orientation, elevation angle, and source distance, were found to be well correlated to the insertion losses. Empirical formulae for the insertion loss prediction were also provided. Owing to the reflection of the balcony ceiling, noise amplification was found at an elevation angle of $30^{\circ}$, for all of the balcony forms tested, when the source was arranged parallel to the building façade. An even stronger amplification of $\sim 2 \mathrm{~dB}$ could be recorded when the source was arranged parallel or perpendicular to the façade, when the elevation angle was further reduced to $15^{\circ}$. This was also the angle at which the horizontal canopy/screen failed to provide any acoustical protection. El-Dien [45] has also carried out a similar study with a standalone multi-storey building, using both a scale model and ray-tracing technique. A closed form balcony with a floor width-to-depth ratio of 5:1 was chosen, and noise reductions of 0.4 to $5 \mathrm{~dB}$ could be achieved. One should note that the noise reduction in El-Dien's study [44] was defined as the noise level difference between the parallel and non-parallel cases.

Furthermore, there have been efforts attempting to improve the acoustical protection of balconies. The installation of sound absorption appears to be the most straight-forward method. Although May [40] indicated that sound absorption (NRC 0.80) could help, the resulting balcony insertion losses in his study were not known, as the associated balconies could not be removed. Hothersall et al. [46] has carried out a two-dimensional simulation to study the effect of sound absorption on the insertion loss of balconies on a multi-storey building next to a road. The absorption adopted was a $100 \mathrm{~mm}$ 
thick fibrous material, with a flow resistance of $20,000 \mathrm{Ns} \cdot \mathrm{m}^{-4}$. In their simulations, the locations for sound absorption installation were the balcony ceiling, the rear wall, the internal surface of the parapet, and the building façade surface facing the road. It was found that the sound absorption installed on the balcony ceiling, was more effective in improving the balcony insertion loss, than those installed at the back of the front parapet and the rear wall. The simulated insertion loss ranged from 5 to $10 \mathrm{~dB}$. The maximum elevation angle in their study was $\sim 60^{\circ}$. Kropp and Bérillon [47] further confirmed the improvement of balcony insertion losses by the installation of sound absorption in the balcony void. The absorption used was a $15 \mathrm{~mm}$ thick fibrous material. Their results are basically in-line with those of Hothersall et al. [46], and illustrate that the balcony ceiling and the rear wall are the most effective locations for installing sound absorption. Their results also show that the insertion loss of their model balcony, when installed with sound absorption, ranged from 4 to $7 \mathrm{~dB}$.

A full scale experimental study on the insertion loss of a balcony-like structure in the presence of sound absorption, has been completed by Tong et al. [48], inside a dual-chamber laboratory facility built for the ISO140-3 test. High density 1-inch thick fibreglass was used as the sound absorption. The sound source was a $\sim 4 \mathrm{~m}$ long loudspeaker array, and the sound incidence angle was $\sim 23^{\circ}$. They found that the balcony ceiling was the most appropriate location for the installation of the artificial sound absorption, in order to improve the broadband insertion loss. This conclusion is similar to that of Hothersall et al. [46]. However, the side walls were found to be the second best location for such installation. The maximum insertion loss was $7 \mathrm{~dB}$. Tong et al. [48] also indicated the importance of acoustic modes in shaping the insertion loss spectra.

The effects of the shapes of a balcony ceiling and parapet on the sound insertion loss, have also attracted the attention of many researchers. El-Dien and Woloszyn [49,50] studied this using the pyramid tracing method, as well as a scale model, to show how the balcony ceiling's inclination and depth, and the front parapet design, could all affect the overall balcony sound insertion loss. They observed that the balcony insertion loss showed an increasing trend with increasing balcony depth. However, the effect of floor height on the insertion loss did not show a well-defined trend, most probably because of the "incident angle sensitive" reflections; the ceiling inclination angle also resulted in no trend being indentified. The balcony insertion loss was found to vary between 0.5 to $6 \mathrm{~dB}$. However, the maximum insertion loss found was 2, 4, and $6 \mathrm{~dB}$, for a balcony depth of $1 \mathrm{~m}, 2 \mathrm{~m}$, and $3 \mathrm{~m}$, respectively, when the front parapet remained vertical [49]. It was also found that an inclined front parapet could result in an additional 0.5 to $4 \mathrm{~dB}$ noise attenuation [50]. However, a $3 \mathrm{~m}$ deep balcony is by no means common in a congested high-rise city.

Lee et al. [51] illustrated the combined effects of the ceiling inclination, sound absorption, and front parapet design, on reducing the noise inside a high-rise building balcony, using a 1:50 sixteen-storey scale model building and simulations. They used $3 \mathrm{~mm}$ thick dense polystyrene as the sound absorption material. They found that the noise reduction could be as high as $23 \mathrm{~dB}$. It should be noted that the noise reduction defined by Lee et al. [51] was the difference in the noise level inside the balcony, with and with the abovementioned special treatments. However, there was only one measurement on the rear wall of the balcony, and thus, the uncertainty in their study could be high. Kan et al. [52] summarized an experience of improving the balcony insertion loss by using sound absorption (NRC 0.60) and a small inclined screen at the balcony edge. A real 40-storey building next to a busy traffic trunk road was chosen for their study. The measured insertion losses with sound absorption installed on the ceiling and side-walls, were within 4 to $5 \mathrm{~dB}$.

In general, sound absorption is not preferred by the users, due to the difficulty in maintaining it. Ishizuka and Fujiwara [53] proposed the use of specially designed hard surface reflectors on the balcony ceiling, in order to reflect incident noise back into open space. The amount of transmitted acoustical energy was thus reduced. By using a site measurement, they showed that the reflectors, when properly oriented, could provide an additional noise reduction of 7 to $10 \mathrm{~dB}$, when compared to that which can be achieved by a conventional balcony. However, the reflectors have to be carefully designed and positioned. A large ceiling height is also required. 
It can be concluded that balconies on a high-rise building do not offer much acoustical protection, unless sound absorption and/or proper ceiling reflectors can be installed. However, reverberation within the street canyons of a high-rise city will largely erase the acoustical protection of the balconies. Nash et al. [54] further illustrated that there would be a drop in speech intelligibility inside the balcony of a high-rise building located within a street canyon, after the installation of sound absorption.

\subsection{Active Noise Control}

The technique of active noise control, which uses a secondary sound to cancel unwanted noise, has been successfully implemented in confined areas (for instance, Trinder and Nelson [55]). Such a system has also been proposed for controlling the noise intrusion into a building's interior, through a ventilation opening [56]. Kwon and Park [57] carried out numerical simulation and experiments, in order to study the effectiveness of an active window system in reducing the noise intrusion through an opened window. Their system consisted of outdoor reference microphones and secondary sources at the window edge facing the building interior. With the appropriate acoustic transfer functions known, no error sensor was required, and the overall sound attenuation between $400 \mathrm{~Hz}$ to $1 \mathrm{kHz}$ in their study, could be as high as $10 \mathrm{~dB}$. However, such a system may not work properly when the building interior is occupied. The transfer functions first have to be determined. The outdoor wind condition can also affect the active control performance.

An acoustic shield design was proposed by Nishimura et al [58]. The idea was to use secondary sources in the ventilation opening, to protect against the intruding sound. In their experiment, a maximum noise reduction of $10 \mathrm{~dB}$ was observed within the frequency range of $500 \mathrm{~Hz}$ to $2 \mathrm{kHz}$. However, the sizes of the control sources were quite large, resulting in a relatively large blockage of the ventilation opening. In conclusion, an active control technique is not often adopted in residential buildings, probably because of system complexity, maintenance issues, and an uncertain reliability, due to the constantly varying living environmental conditions, both indoors and outdoors.

\subsection{Plenum Windows/Double-Wall Structures with Staggered Air Inlet and Outlet}

Although double glazing windows do not allow for natural ventilation, a partially opened one will allow for some degree of air movement across it, while the sound transmission loss may still be acceptable. Ford and Kerry [59] carried out a series of tests on the sound transmission losses across slightly opened double glazing windows. The two window openings in their experiment were staggered, and the air gap between the two window glass panes formed an air passage. A window design with a width of $2.4 \mathrm{~m}$, a window frame separation of $200 \mathrm{~mm}$, and an opening size of $30 \mathrm{~mm}$, could provide a $9 \mathrm{~dB}$ higher traffic noise reduction than an opened single window.

Although the $30 \mathrm{~mm}$ opening width of Ford and Kerry [59] is far too small for meaningful natural ventilation, this window type has recently attracted attention. It is now commonly referred to as a ventilation window or plenum window $[60,61]$ (hereinafter referred to as plenum window). This device is a double-walled (usually glass panes) plenum structure, with a staggered air inlet and outlet. The plenum window can be categorized into the horizontal and vertical type, according to the orientation of the openings, as shown in Figure 4. However, the corresponding noise reduction mechanisms are basically the same. In order to provide meaningful air movement across the window for acceptable natural ventilation, the sizes of the openings have to be increased. Søndergaard and Legarth [62] conducted both laboratory and site tests on an air supply window in Denmark. Their window type was of the vertical plenum window type, without sound absorption material. The opening sizes of their vents, though larger than those of Ford and Kerry [59], were still small compared to the physical length of the window, probably because of the Scandinavian climate. The corresponding noise reduction $R_{w}+C_{t r}$ ranged from 16 to $24 \mathrm{~dB}$. However, such a window design is not suitable for use in tropical or sub-tropical regions. Bajraktari et al. [63] showed that their double-facade system, which was basically a plenum window setup, could offer a noise reduction, $R_{w}$, of between 18 to $26 \mathrm{~dB}$, when no sound absorption material was applied. 
A parametric study on the sound insertion loss of a horizontal type plenum window was carried out by Tong and Tang [61], using 1:4 scale model experiments. The effect of the window orientation, relative to the sound source, $\theta$, was also tested. Their results show that, for a fixed overall window width $L$, the insertion loss of a plenum window generally increased with increasing overlapping length $G$, but decreased with increasing window opening sizes $\left(W_{1}\right.$ and $\left.W_{2}\right)$, or gap width $D$. In their study, the overall window width, $L$, equals $G+W_{1}+W_{2}$ and $W_{1}=W_{2}=W$. The maximum and minimum traffic noise insertion loss increases, achieved by replacing an opened casement window with a plenum window of the same overall window size, where $0.1 \leq G / L \leq 0.2,0.1 \leq W / L \leq 0.5$ and $-90^{\circ} \leq \theta \leq 90^{\circ}$ were $15 \mathrm{~dB}$ and $5 \mathrm{~dB}$, respectively. The maximum insertion loss was recorded within $-30^{\circ} \leq \theta \leq 30^{\circ}$, while the minimum wasrecorded at $\theta=-90^{\circ}$ or $90^{\circ}$. The effect of the window height was not examined, as this height should be more or less fixed in practice.

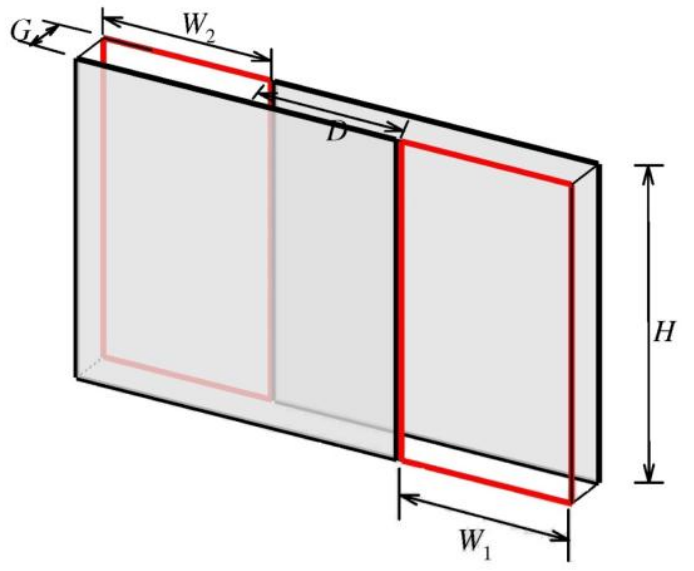

(a)

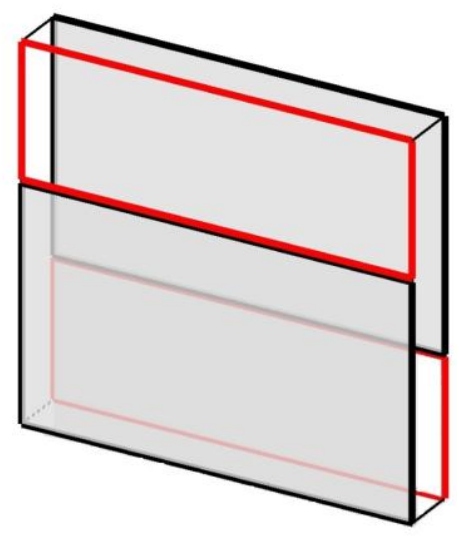

(b)

Figure 4. Basic plenum window schematics and nomenclature. (a) Horizontal type; (b) vertical type. Red lines: boundaries of window openings; grey shaded areas: glass panes.

The insertion losses of the horizontal type plenum windows were further tested using a site mockup, whose façade was next to and parallel to a busy trunk road [64]. In this mockup, two side-by-side standard residential units of a Hong Kong public housing estate, were constructed. One of them was equipped with plenum windows, while the other represented normal provision (side-hung casement windows). Measurements inside and outside these units were conducted simultaneously, such that the acoustical benefit of replacing the side-hung casement windows with plenum windows, could be estimated in-situ. Figure 5 illustrates the dimensions of the two plenum windows tested. The insertion losses of both the individual plenum windows and their combined version, were measured. The results, after correcting for the room reverberation effect, show that there was an additional 7 to $9 \mathrm{~dB}$ traffic noise reduction when adopting plenum windows. The gap widths of these windows were small, at $175 \mathrm{~mm}$, but the computed natural ventilation rate met the local statutory requirement of 1.5 air-change per hour.

Furthermore, there have been proposals for improving the insertion loss of a plenum window. Kang and Brocklesby [60] conducted a detailed experimental investigation on the benefit of using micro-perforated absorbers in acoustic chambers. Many different ways of installing the micro-perforated absorber were included. Their results suggest that the application of micro-perforated absorbers inside a plenum window air gap, could increase the average sound level difference (arithmetic average from 500 to $8000 \mathrm{~Hz}$ ) across a plenum window, by approximately 2 to $6 \mathrm{~dB}$. The extent of this improvement increased with an increasing gap width, and the average sound level differences ranged from $\sim 29$ to $33 \mathrm{~dB}$. The spectral average sound level differences roughly varied between 15 to $40 \mathrm{~dB}$, within the $125 \mathrm{~Hz}$ to $8 \mathrm{kHz}$ one-third octave bands. Their results also indicate 
that an air speed of $2 \mathrm{~m} / \mathrm{s}$ inside the air passage did not affect the noise reduction capacity of the plenum windows.

Another example has been produced by Kang and Li [65], who carried out finite-element simulations in an attempt to further understand the sound transmission characteristics of plenum windows. Apart from the effect of sound absorption lining on the glass panes, discussed in Kang and Brocklesby [60], it was found that sound absorptive louvers and a hood, hung at the outdoor opening, could significantly improve the noise reduction performance of the windows. Their computed spectral sound level differences roughly varied between 22 to $50 \mathrm{~dB}$, within the $125 \mathrm{~Hz}$ to $1 \mathrm{kHz}$ one-third octave bands, in the presence of absorptive louvers. The hood resulted in spectral sound level differences which fluctuated between 8 to $40 \mathrm{~dB}$. In general, the longer the vertical hood length was, the higher the sound level difference was. However, the resonance significantly affected the shapes of the sound level difference spectra.
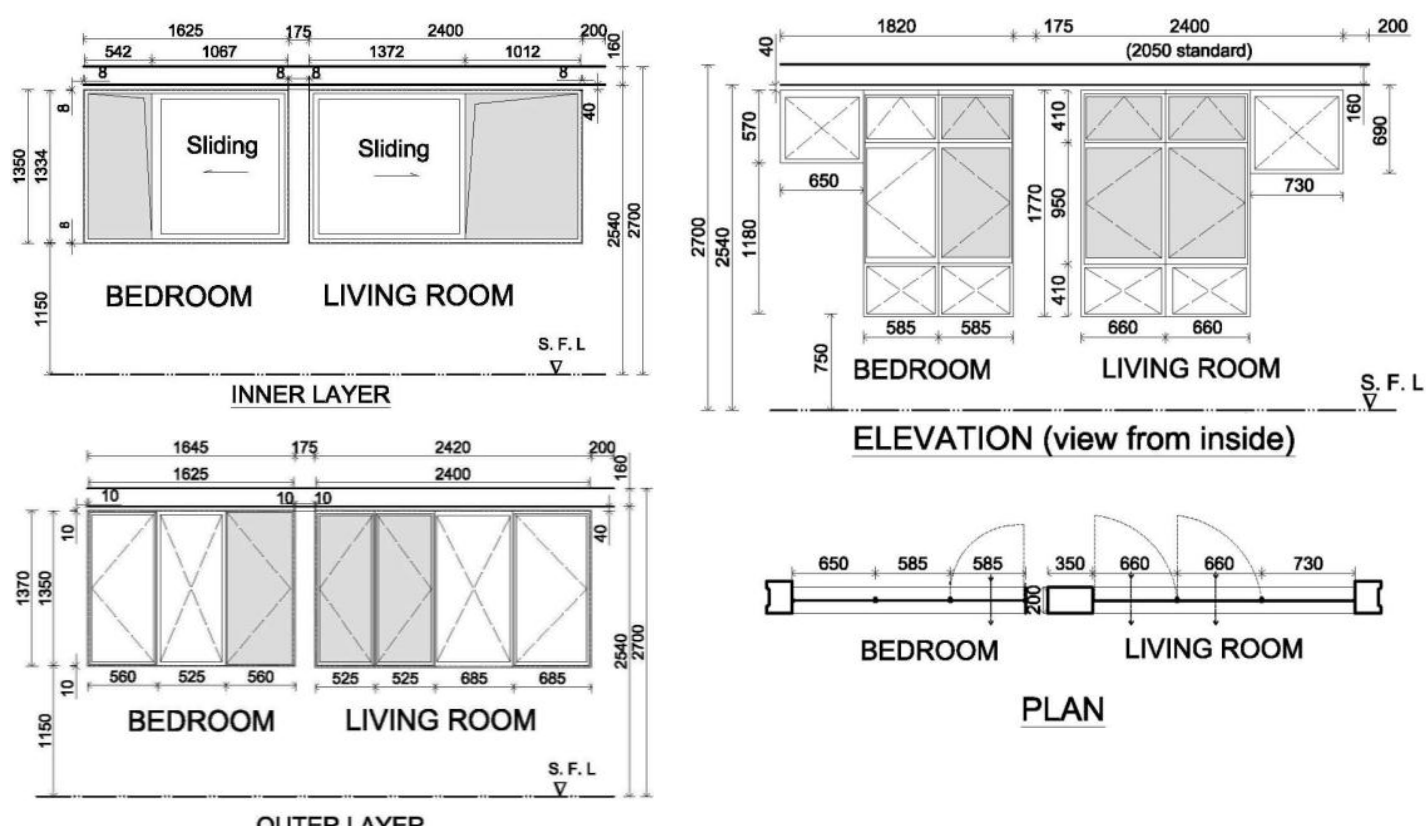

OUTER LAYER

\section{ELEVATION (view from inside)}

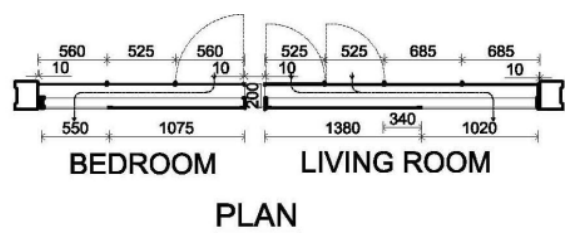

(a)

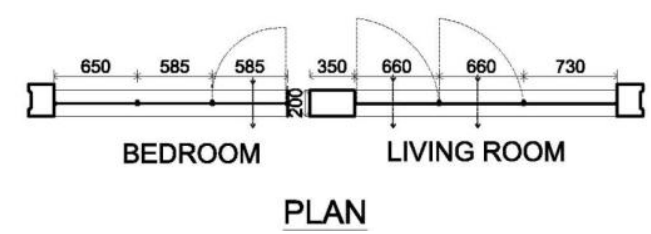

(b)

Figure 5. Dimensions and configurations of the plenum windows and casement windows tested previously by the author (extracted from [64]). (a) Plenum windows; (b) casement windows. Copyright Elsevier, 2015.

Site measurement, involving a vertical plenum window, was pursued at a student hostel in Hong Kong, in order to investigate the acoustical benefit that could be achieved by lining sound absorption over the different internal surfaces of a plenum window [66]. The dimensions of the tested window were similar to those of Kang and Brocklesby [60]. The sound absorption materials used were two-inch thick high density fibreglass (NRC 1.00), and micro-perforated absorbers with a $50 \mathrm{~mm}$ air gap between them and the glass panes (NRC 0.45 ). Without any additional sound absorption inside 
the window, the difference between the average indoor sound level and that at $1 \mathrm{~m}$ from the outer glass pane, was $19 \mathrm{~dB}$. The maximum improvement in noise reduction was $23 \mathrm{~dB}$, which was achieved with all of the concrete/tile surfaces, when the outer surface of the indoor window glass pane was lined with the fibreglass and micro-perforated absorbers.

Tang [67] further studied how the noise reduction of the plenum window of Tang [66] would be affected by tilting the indoor glass pane, using a 1:4 scale model. Owing to the limited gap width, the tilt angles could only be varied from $-5^{\circ}$ to $5^{\circ}$. The source was arranged parallel to the model façade, and no sound absorption was applied. The effects of the sound incident angle $\left(7^{\circ}\right.$ to $\left.35^{\circ}\right)$ were also examined. It was found that the direction of tilting had no significant effect on the noise reduction. The noise reduction improvement varied from 0 to $4 \mathrm{~dB}$.

More recently, Lee [68] discussed the sound transmission loss of, and the air ventilation across, double-skin curtain façades. He also computed the air temperature distributions inside the curtain wall cavities. This design can be regarded as a plenum window of a much larger physical dimension than those discussed above. Glass fins could be installed within the air cavities of these structures. The sound transmission class (STC) of the tested curtain walls ranged from 30 to 40, depending on the air cavity width and the fin thickness.

There have also been efforts to explore the use of active noise control for the improvement of plenum window noise reduction. Through the use of scale model experiments, Huang et al. [69] showed that the control was only satisfactory at frequencies below the cut-on frequency of the first odd mode in the gap direction. They found that there was a $20 \mathrm{~dB}$ additional noise reduction when the active control was applied. Qiu et al. [70] built a prototype plenum window, with a window cavity that was divided into two rectangular channels, using a horizontal glass pane to test the performance of the active noise control. They showed that their active control system could improve the noise reduction by an average of $12 \mathrm{~dB}$, over a frequency range of 200 to $800 \mathrm{~Hz}$. Tang et al. [71] carried out a full-scale model active control test with a horizontal plenum window and a single compact primary source, in the laboratory. They found that two secondary loudspeakers, installed symmetrically above the horizontal plenum window centreline, inside the window directly facing the incoming sound, were sufficient enough to provide the control. In addition, they indicated that a better active control performance could be achieved when the receiver room was less reverberant. However, the additional noise reduction due to the active control was found to be limited to below $5 \mathrm{~dB}$, except at some individual frequencies, at which the noise reduction was above $10 \mathrm{~dB}$. In addition, as in the study of Huang et al. [69], noise reduction improvement could only be found at frequencies below the first gap mode cut-on.

The performance of a plenum window is, in general, not affected by city reverberation. However, the air movement, and thus the associated natural ventilation effectiveness, largely depend on the availability of outdoor wind. The current window design tested by the author may thus not be applicable in areas where the air is stuffy for most of the year. Also, the level of natural ventilation depends on the possibility of cross ventilation inside the residential units equipped with plenum windows.

\section{Remarks and Current Challenges}

Table 1 summarizes the performance of the natural ventilation-enabling noise control devices, reviewed in Section 2. Their limitations are also reviewed. It can be seen that protrusive devices, such as lintels, eaves, fins, and balconies, are not effective noise screening devices for use in a congested high-rise living environment. Active noise control systems and resonance-based devices are also not desirable noise control solutions. 
Table 1. Acoustical Performances of Natural Ventilation-enabling Noise Control Devices.

\begin{tabular}{|c|c|c|c|}
\hline Device & Indicative References & Noise Reduction & Comments and Remarks \\
\hline \multirow{4}{*}{$\begin{array}{l}\text { Fins, lintels, screens and } \\
\text { similar protrusions }\end{array}$} & Janczu et al. [24] & $3 \mathrm{~dB} \max$. & \multirow{4}{*}{$\begin{array}{l}\text { Not suitable for use in high-rise buildings unless significant sound } \\
\text { absorption and/or reflectors can be installed at appropriate locations. } \\
\text { Performance can be affected by sound incidence angle and relative } \\
\text { orientations of the windows to noise sources. } \\
\text { City reverberation will reduce noise reduction capacities. }\end{array}$} \\
\hline & Tadeu et al. [25] & $-0.2-7 \mathrm{~dB}$ at $1 \mathrm{kHz}$ & \\
\hline & Sakamoto et al. [28] & $\begin{array}{l}1 \text { to } 10 \mathrm{~dB} \text {, but sound incidence angle has to be as large as } 80^{\circ} \text { for the } \\
\text { insertion loss to be higher than } 4 \mathrm{~dB}\end{array}$ & \\
\hline & Martello et al. [29] & $\begin{array}{l}\text { Façade sound insulation index (window closed): } 20 \text { to } \sim 40 \mathrm{~dB} \text { from } \\
100 \text { to } 5 \mathrm{kHz} 1 / 3 \text { octave bands }\end{array}$ & \\
\hline \multirow{3}{*}{ Resonant devices } & Field [32] & $R_{w}=22 \mathrm{~dB}$ & \multirow{3}{*}{$\begin{array}{l}\text { Bulky device. } \\
\text { Tends to block air ventilation passage } \\
\text { Not suitable for congested cities }\end{array}$} \\
\hline & Asakura et al. [34] & $\begin{array}{l}\text { Noise level difference between two sides of the associated window: } \\
\sim 20 \mathrm{~dB}\end{array}$ & \\
\hline & Nguyen et al. [35] & $2-9 \mathrm{~dB}, 500 \mathrm{~Hz}$ to $8 \mathrm{kHz}$ octave bands & \\
\hline \multirow{10}{*}{ Balconies } & Mohsen and Oldham [37] & $\sim 5 \mathrm{~dB}$ traffic noise insertion loss on average for a closed form balcony & \multirow{10}{*}{$\begin{array}{l}\text { Massive structures, but relatively weak noise reduction. } \\
\text { Not suitable for use in high-rise buildings unless significant sound } \\
\text { absorption and/or reflectors can be installed at appropriate locations. } \\
\text { Floor height limits the use of reflectors in many cases. } \\
\text { Performance is affected by sound incidence angle and relative } \\
\text { orientation of the windows to noise sources. } \\
\text { City reverberation will reduce noise reduction capacities. } \\
\text { Use of sound absorption will lower down speech intelligibility } \\
\text { inside balconies. } \\
\text { Courtyard/recessed building design could result in poor natural } \\
\text { ventilation. Less number of residential units can be built. }\end{array}$} \\
\hline & Oldham and Mohsen [39] & Traffic noise reduction: $\sim 5 \mathrm{~dB}-\sim 14 \mathrm{~dB}$ for recessed building & \\
\hline & Hammad and Gibbs [41] & Courtyard with thnadner: $8-26 \mathrm{dBC}$ ourtyard with splitter: $10-27 \mathrm{~dB}$ & \\
\hline & El-Dien [45] & Closed form balcony: $0.4-5 \mathrm{~dB}$ & \\
\hline & Hothersall et al. [46] & Insertion loss: 5-10 dB (2D simulation) & \\
\hline & Kropp and Bérillon [47] & Insertion loss: $4-7 \mathrm{~dB}$ & \\
\hline & Tong et al. [48] & Insertion loss: $7 \mathrm{~dB}$ max. & \\
\hline & El-Dien and Woloszyn $[49,50]$ & Insertion loss: $0.5-6 \mathrm{~dB}$ & \\
\hline & Kan et al. [52] & Insertion loss: $4-5 \mathrm{~dB}$ & \\
\hline & Ishizuka and Fujiwara [53] & 7-10 dB higher noise reduction than conventional balconies & \\
\hline \multirow{2}{*}{ Active noise control } & Kwon and Park [57] & $\begin{array}{l}10 \mathrm{~dB} \text { max., } \\
400 \mathrm{~Hz} \text { to } 1 \mathrm{kHz}\end{array}$ & \multirow{2}{*}{$\begin{array}{l}\text { Active control installation usually results in bulky systems. } \\
\text { Tends to block air ventilation passage in some cases. } \\
\text { Its effectiveness is affected by parameters which cannot be controlled. } \\
\text { Not reliable for building façade application. }\end{array}$} \\
\hline & Nishimura et al. [58] & $\begin{array}{l}10 \mathrm{~dB} \text { max., } \\
500 \mathrm{~Hz} \text { to } 2 \mathrm{kHz}\end{array}$ & \\
\hline \multirow{7}{*}{$\begin{array}{l}\text { Plenum windows/ } \\
\text { Double-wall plenum } \\
\text { structures with staggered } \\
\text { air inlet and outlet }\end{array}$} & Kang and Brocklesby [60] & Average sound level differences across window: $\sim 29-33 \mathrm{~dB}$ & \multirow{7}{*}{$\begin{array}{l}\text { Able to provide noise protection and enable reasonable } \\
\text { natural ventilation. } \\
\text { Can be used together with the above devices or other measures for } \\
\text { enhanced noise screening performance. } \\
\text { Performance can be affected by sound incidence angle and relative } \\
\text { orientation of the windows to noise sources. } \\
\text { Performance is not much affected by city reverberation. } \\
\text { Have rooms for further improvements and research }\end{array}$} \\
\hline & Tong and Tang [61] & Traffic noise insertion loss: $5-15 \mathrm{~dB}$ & \\
\hline & Søndergaard and Legarth [62] & $R_{w}+C_{t r}: 16-24 \mathrm{~dB}$ & \\
\hline & Bajraktari et al. [63] & $R_{w}: \sim 18-26 \mathrm{~dB}$ & \\
\hline & Tong et al. [64] & Traffic noise insertion loss: 7-9 dB & \\
\hline & Tang [66] & Traffic noise level differences across window: $19-23 \mathrm{~dB}$ & \\
\hline & Lee $[[68]]$ & Plenums with fin: STC 30-40 & \\
\hline
\end{tabular}


On the contrary, double-wall plenum structures with a staggered air inlet and outlet, especially the plenum windows, are found to provide noise protection, and at the same time, allow air movement across them to enable natural ventilation. They can also be used together with other noise mitigation measures, such as sound absorbers and active noise control, for an enhanced noise reduction performance. Their performances are much less affected by city reverberation. All of these properties make this type of devices very useful for congested high-rise cities, especially those in tropical and sub-tropical climates. They have been attracting worldwide attention in recent years. Efforts have also been focused on the prediction of plenum window acoustical performances (for instance, Yu et al. [72]).

Plenum windows have been adopted in several housing estates in Hong Kong. However, as the less noisy areas are becoming increasingly inhabited, one has to work with more difficult sites. There are at least two questions to be answered. Can one obtain a stronger noise reduction without affecting the natural ventilation, or vice versa? And, can one improve both the natural ventilation and the noise reduction at the same time? Further studies for improving the acoustical performance of plenum windows are currently being carried out by the author.

\section{Conclusions}

A review has been pursued in an attempt to summarize the continuous efforts of researchers in the research and development of natural ventilation-enabling noise control devices. These devices have been proposed for use in high-rise buildings in congested cities with serious traffic noise pollution. This review also updates the relevant parts of a previous review completed in 2002 by another research team, with the addition of more recent information and new developments.

In general, protrusive devices, such as balconies, lintels, and fins, are not effective noise screening devices for high-rise buildings in congested cities, even when sound absorbers and/or reflectors are installed, due to city reverberation. Together with sound absorbers, they are only useful in semi-enclosed or open environmental conditions, where the multi-reflections from nearby buildings are either absent or insignificant. However, their screening effects are still limited, especially at lower floors which are closer to the ground traffic.

Active control installation and resonance-based devices usually result in bulky systems. The air ventilation passage can be seriously blocked in some cases. The active control effectiveness can also be affected by parameters which cannot be controlled, making such complicated systems unreliable for building façade application.

Plenum windows and other similar double-wall plenum structures with a staggered air inlet and outlet, are found to be useful as natural ventilation-enabling noise control devices, on building façades in the tropical and sub-tropical climatic regions. Based on the results in existing literature and the experience of the author and others, this window type should be useful in high-rise environments, even when considerable city reverberation exists. They have been adopted in several housing projects in Hong Kong. However, since one has to work with more extreme sites in the near future, as the less nosy sites will gradually be used up, it is time to start investigating the ways to improve both the noise reduction of, and the air movement across, these plenum structures.

Acknowledgments: This review study is financial supported by The Research Grant Council, The Hong Kong Special Administration Region Government under Project number GRF 152164/15E.

Conflicts of Interest: The author declares no conflict of interest.

\section{References}

1. Kang, J.; Chourmouziadou, K.; Sakantamis, K.; Wang, B.; Hao, Y. Soundscape of European Cities and Landscapes; COST-TD0804; Soundscape-COST: Oxford, UK, 2013.

2. Burden of Disease from Environmental Noise. Quantification of Healthy Life Years Lost in Europe; World Health Organization: Bonn, Germany, 2011.

3. Scholes, W.E. Traffic noise criteria. Appl. Acoust. 1970, 3, 1-21. [CrossRef] 
4. Li, H.N.; Chau, C.K.; Tang, S.K. Can surrounding greenery reduce noise annoyance at home? Sci. Total Environ. 2010, 408, 4376-4384. [CrossRef] [PubMed]

5. Dzhambov, A.M.; Dimitrova, D.D. Green spaces and environmental noise perception. Urban For. Urban Green. 2015, 14, 1000-1008. [CrossRef]

6. Van Renterghem, T.; Botteldooren, D. View on outdoor vegetation reduces noise annoyance for dwellers near busy roads. Landsc. Urban Plan. 2016, 148, 203-215. [CrossRef]

7. Zhang, B.; Shi, L.; Di, G. The influence of the visibility of the source on the subjective annoyance due to its noise. Appl. Acoust. 2003, 64, 1205-1215.

8. Aletta, F.; Masullo, M.; Maffei, L.; Kang, J. The effect of vision on the perception of the noise produced by a chiller in a common living environment. Noise Control Eng. J. 2016, 64, 363-378. [CrossRef]

9. World Urbanization Prospects: The 2014 Revision, Highlights; Department of Economic and Home Affairs, United Nations, 2014.

10. Kurze, U.J.; Anderson, G.S. Sound attenuation by barriers. Appl. Acoust. 1971, 4, 35-53. [CrossRef]

11. Okubo, T.; Fujiwara, K. Efficiency of a noise barrier on the ground with an acoustically soft cylinder edge. J. Sound Vib. 1998, 216, 771-790. [CrossRef]

12. Hart, C.R.; Lau, S.K. Active noise control with linear control source and sensor arrays for a noise barrier. J. Sound Vib. 2012, 331, 15-26. [CrossRef]

13. Li, K.M.; Tang, S.H. The predicted barrier effects in the proximity of tall buildings. J. Acoust. Soc. Am. 2003, 114, 821-832. [CrossRef] [PubMed]

14. Takagi, K.; Miyake, T.; Yamamoto, K.; Tachibana, H. Prediction of road traffic noise around tunnel mouth. In Proceedings of the 29th International Congress and Exhibition on Noise Control Engineering, Nice, France, 27-30 August 2000.

15. Hong Kong Planning Standard and Guidelines; Environmental Protection Department, The HKSAR Government: Hong Kong, China, 1990.

16. Öhrström, E.; Skånberg, A.; Svensoon, H.; Gidlöf-Gunnarsson, A. Effects of road traffic noise and the benefit of access to quietness. J. Sound Vib. 2006, 295, 40-59. [CrossRef]

17. Echevarria Sanchez, G.M.; van Renterghem, T.; Thomas, P.; Botteldooren, D. The effect of street canyon design on traffic noise exposure along roads. Build. Environ. 2016, 97, 96-110. [CrossRef]

18. Tadeu, A.J.B.; Mateus, D.M.R. Sound transmission through single, double and triple glazing. Experimental evaluation. Appl. Acoust. 2001, 62, 307-325. [CrossRef]

19. Asdrubali, F.; Buratti, C. Sound intensity investigation of the acoustics performances of high insulation ventilating windows integrated with rolling shutter boxes. Appl. Acoust. 2005, 66, 1088-1101. [CrossRef]

20. De Salis, M.H.F.; Oldham, D.J.; Sharples, S. Noise control strategies for naturally ventilated buildings. Build. Environ. 2002, 37, 471-484. [CrossRef]

21. BS EN1793-3. Road Traffic Noise Reducing Devices—Test Methods for Determining the Acoustic Performance-Part 3. Normalized Traffic Noise Spectrum; ISO: London, UK, 1998.

22. Delany, M.E.; Rennie, A.J.; Collins, K.M. Scale Model Investigation of Traffic Noise Propagation; National Physical Laboratory: Teddington, UK, 1972.

23. Department of Transport, Welsh Office. Calculation of Road Traffic Noise; HMSO: London, UK, 1988.

24. Janczu, J.; Walerian, E.; Czechowicz, M. Façade shaping as local means protecting against traffic noise. Acta Acust. United Acust. 2011, 97, 769-778. [CrossRef]

25. Tadeu, A.; Antónia, J.; Amado Mendes, L.; Godinho, L. Sound pressure level attenuation provided by thin rigid screens coupled to tall buildings. J. Sound Vib. 2007, 304, 479-496. [CrossRef]

26. Szokolay, S.V. Introduction to Architectural Science: The Basis of Sustainable Design; Architectural Press: Oxford, UK, 2008.

27. Tang, S.K. Noise screening effects of balconies on a building façade. J. Acoust. Soc. Am. 2005, 118, $213-221$. [CrossRef] [PubMed]

28. Sakamoto, S.; Ito, K.; Asakura, T. Experimental study on the noise shielding effects of eaves attached on building façade. In Proceedings of the 37th International Congress and Exposition on Noise Control Engineering, Shanghai, China, 26-29 October 2008.

29. Zuccherini Martello, N.; Fausti, N.; Santoni, P.; Secchi, S. The use of sound absorbing shading systems for the attenuation of noise on building façades. An experimental investigation. Buildings 2015, 5, 1346-1360. [CrossRef] 
30. Ko, N.W.M. Reverberation time in a high-rise city. J. Sound Vib. 1978, 56, 459-461. [CrossRef]

31. Zuccherini Martello, N.; Aletta, F.; Fausti, P.; Kang, J.; Secchi, S. A psychoacoustic investigation on the effect of external shading devices on building façades. Appl. Sci. 2016, 6, 429. [CrossRef]

32. Field, C. The latest developments of an attenuator for naturally ventilated buildings. In Proceedings of the 33rd International Congress and Exposition on Noise Control Engineering, Prague, Czech Republic, 22-25 August 2004.

33. Tang, S.K. Narrow sidebranch arrays for low frequency duct noise control. J. Acoust. Soc. Am. 2012, 132, 3086-3097. [CrossRef] [PubMed]

34. Asakura, T.; Sakamoto, S.; Rikitake, H.; Higuchi, Y.; Sakamoto, Y.; Satoh, F.; Tachibana, H. Development of duct-like ventilation system with high sound insulation. In Proceedings of the 35th International Congress and Exposition on Noise Control Engineering, Honolulu, HI, USA, 3-6 December 2006.

35. Nguyen, Q.H.; Takashima, Y.; Nishimura, T.; Nishimura, S.; Nishimura, Y. Wave analysis of soundproofing ventilation grille. In Proceedings of the 41st International Congress and Exposition on Noise Control Engineering, New York, NY, USA, 19-22 August 2012.

36. Eveno, C. A balcony in a city-Imagination in architecture. Archit. d'Aujourd'hui 1995, 299, 3.

37. Mohsen, E.A.; Oldham, D.J. Traffic noise reduction due to the screening effect of balconies on a building façade. Appl. Acoust. 1977, 10, 243-257. [CrossRef]

38. Oldham, D.J.; Mohsen, E.A. The acoustical performance of self-protecting buildings. J. Sound Vib. 1979, 65, 557-581. [CrossRef]

39. Oldham, D.J.; Mohsen, E.A. A technique for predicting the performance of self-protecting buildings with respect to traffic noise. Noise Control Eng. J. 1980, 15, 11-19. [CrossRef]

40. May, D.N. Freeway noise and high-rise balconies. J. Acoust. Soc. Am. 1979, 65, 699-704. [CrossRef]

41. Hammad, R.N.S.; Gibbs, B.M. The acoustic performance of building façades in hot climates: Part I-Courtyards. Appl. Acoust. 1983, 16, 121-137. [CrossRef]

42. Hammad, R.N.S.; Gibbs, B.M. The acoustic performance of building façades in hot climates: Part II-Closed balconies. Appl. Acoust. 1983, 16, 441-454. [CrossRef]

43. Writ, L.S. The control of diffracted sound by means of thnadners (shaped noise barriers). Acta Acust. United Acust. 1979, 42, 73-88.

44. Tang, S.K. Scale model study of balcony insertion losses on a building façade with non-parallel line sources. Appl. Acoust. 2010, 71, 947-954. [CrossRef]

45. Hussain El-Dien, H. The influence of an inclined line source close to building façades with balconies. Noise Control Eng. J. 2012, 60, 363-373. [CrossRef]

46. Hothersall, D.C.; Horoshenkov, K.V.; Mercy, S.E. Numerical modeling of the sound field near a tall building with balconies near a road. J. Sound Vib. 1996, 198, 507-515. [CrossRef]

47. Kropp, W.; Bérillon, J. A theoretical model to consider the influence of absorbing surfaces inside the cavity of balconies. Acta Acust. United Acust. 2000, 86, 485-494.

48. Tong, Y.G.; Tang, S.K.; Yeung, M.K.L. Full-scale model investigation on the acoustical protection of a balcony-like façade device. J. Acoust. Soc. Am. 2011, 130, 673-676. [CrossRef] [PubMed]

49. Hussain El-Dien, H.; Woloszyn, P. Prediction of the sound field into high-rise building façades due to balcony ceiling form. Appl. Acoust. 2004, 63, 431-440. [CrossRef]

50. Hussain El-Dien, H.; Woloszyn, P. The acoustical influence of balcony depth and parapet form: Experiments and simulations. Appl. Acoust. 2005, 66, 533-551. [CrossRef]

51. Lee, P.J.; Kim, Y.H.; Jeon, J.Y.; Song, K.D. Effects of apartment building façade and balcony design on the reduction of exterior noise. Build. Environ. 2007, 42, 3517-3528. [CrossRef]

52. Kan, J.; Chan, I.; Ng, I.; Yeung, M.; Tang, S.K.; Lo, P. Study of noise reduction effect of acoustic balconies in high-rise buildings. In Proceedings of the 44th International Congress and Exposition on Noise Control Engineering, San Francisco, CA, USA, 9-12 August 2015.

53. Ishizuka, T.; Fujiwara, K. Traffic noise reduction at balconies on a high-rise building façade. J. Acoust. Soc. Am. 2012, 131, 2110-2117. [CrossRef] [PubMed]

54. Naish, D.A.; Tan, A.C.C.; Demirbilek, F.N. Speech interference and transmission on residential balconies with road traffic noise. J. Acoust. Soc. Am. 2013, 133, 210-226. [CrossRef] [PubMed]

55. Trinder, M.C.J.; Nelson, P.A. Active noise control in finite length ducts. J. Sound Vib. 1983, 89, 95-105. [CrossRef] 
56. Anai, K.; Shiki, T. Improving sound insulation capacity at a ventilation opening using active noise control: Improving sound insulation performance degraded by living sound. In Proceedings of the 37th International Congress and Exposition on Noise Control Engineering, Shanghai, China, 26-29 October 2008.

57. Kwon, B.; Park, Y. Interior noise control with an active window system. Appl. Acoust. 2013, 74, 647-652. [CrossRef]

58. Nishimura, M.; Ohnishi, K.; Kanamori, N.; Ito, K. Basic study on active acoustic shielding. In Proceedings of the 37th International Congress and Exposition on Noise Control Engineering, Shanghai, China, 26-29 October 2008.

59. Ford, R.D.; Kerry, G. The sound insulation of partially open double glazing. Appl. Acoust. 1972, 6, 57-72. [CrossRef]

60. Kang, J.; Brocklesby, M.W. Feasibility of applying micro-perforated absorbers in acoustic window systems. Appl. Acoust. 2005, 66, 669-689. [CrossRef]

61. Tong, Y.G.; Tang, S.K. Plenum window insertion loss in the presence of a line source-A scale model study. J. Acoust. Soc. Am. 2013, 133, 1458-1467. [CrossRef] [PubMed]

62. Søndergaard, L.S.; Legarth, S.V. Investigation of sound insulation for a supply air window-Field measurements and occupant responses. In Proceedings of the 43rd International Congress and Exposition on Noise Control Engineering, Melbourne, Australia, 16-19 November 2014.

63. Bajraktari, E.; Lechleitner, J.; Mahdavi, A. Estimating the sound insulation of double facades with openings for natural ventilation. Energy Procedia 2015, 78, 140-145. [CrossRef]

64. Tong, Y.G.; Tang, S.K.; Kang, J.; Fung, A.; Yeung, M.K.L. Full scale field study of sound transmission across plenum windows. Appl. Acoust. 2015, 89, 244-253. [CrossRef]

65. Kang, J.; Li, Z. Numerical simulation of an acoustic window system using finite element method. Acta Acust. United Acoust. 2007, 93, 152-163.

66. Tang, S.K. Acoustical protection of a plenum window installed with sound absorptions. In Proceedings of the 44th International Congress and Exposition on Noise Control Engineering, San Francisco, CA, USA, 9-12 August 2015.

67. Tang, S.K. Sound transmission across plenum windows with non-parallel glass panes. In Proceedings of the 45th International Congress and Exposition on Noise Control Engineering, Hamburg, Germany, 21-24 August 2016.

68. Lee, J. Ventilation and sound attenuation potential of double-skin façades in urban high-rises. CTBUH J. 2016, 1, 32-37.

69. Huang, H.H.; Qiu, X.J.; Kang, J. Active noise attenuation in ventilation windows. J. Acoust. Soc. Am. 2011, 130, 176-188. [CrossRef] [PubMed]

70. Qiu, X.J.; Huang, H.H.; Lin, Z. Progress in research on natural ventilation ANC windows. In Proceedings of the 40th International Congress and Exposition on Noise Control Engineering, Osaka, Japan, 4-7 September 2011.

71. Tang, S.K.; Tong, Y.G.; Tsui, K.L. Sound transmission across a plenum window with an active noise cancellation system. Noise Control Eng. J. 2016, 64, 423-432. [CrossRef]

72. Yu, X.; Lau, S.K.; Cheng, L.; Cui, F. A numerical investigation on the sound insulation of ventilation windows. Appl. Acoust. 2017, 117, 113-121. [CrossRef]

(C) 2017 by the author; licensee MDPI, Basel, Switzerland. This article is an open access article distributed under the terms and conditions of the Creative Commons Attribution (CC BY) license (http:/ / creativecommons.org/licenses/by/4.0/). 